\title{
The Importance of Image for a Regular Event
}

\author{
Ananda Sabil Hussein \\ Department of Management, Faculty of Economics and Business \\ Universitas Brawijaya Indonesia; sabil@ub.ac.id \\ Raditha Hapsari \\ Faculty of Agribusiness and Commerce, Lincoln University Canterbury, New Zealand
}

\section{Doi:10.5901/mjss.2015.v6n6s4p28}

\begin{abstract}
This study aims to investigate the importance of event image in creating visitor revisit intention of a regular event. A covariance based SEM with a confirmatory factor analysis was employed to analyse the data. Two hundred and five respondents participated in this study were recruited by using convenience sampling method. The results show that event image plays an important role in creating visitor revisit intention of a regular event. In addition to its direct effect on revisit intention, event image was also found to have a full mediating effect on the relationship between event awareness and visitor revisit intention. Upon the completion of hypotheses testing, this study contributes to both theoretical and practical perspectives. For theoretical standpoint, this study provides an insight about the importance of event image in the area of destination branding. For practical perspective, this study provides an input for event organizers or city council in creating a positive image for a regular event in order to enhance visitor loyalty.
\end{abstract}

Keywords: regular event, event image, event awareness, revisit intention, SEM

\section{Introduction}

The event industry is one of the world's largest employers which contributes major positive economic impact (Kose, Argan, \& Argan, 2011). Events can be differentiated into mega event and regular event. Regular events are usually held on weekly or monthly basis and should be determined as one of tourism destinations. Trošt, Klarić, and Ružić (2012) suggest that event is an important component for destination branding. Scholars (Cai, 2002; Hsing-Hui Lin, 2011) explain that developing a destination brand is more difficult rather than developing brand of product or service since destination brand has more complex elements such as the tourist interaction, tourism policy and tourism industry.

In the context of brand management, image has been recognized widely as an important construct in creating brand equity (Keller, 1993). Some studies found that brand image has a positive effect on behavioural intention (Bloemer \& de Ruyter, 1998; Kandampully \& Suhartanto, 2000; Suhartanto, Clemes, \& Dean, 2013). These studies contend that the more positive image perceived by the customers, then the higher their intention to loyal. In accord to these studies, some studies in the area of tourism have identified the importance of event or festival image (Gibson, Qi, \& Zhang, 2008; Kaplanidou \& Vogt, 2007; Moon, Ko, Connaughton, \& Lee, 2013; Wong, Wu, \& Cheng, 2014). These studies indicate that individuals have intention to revisit an event or a festival when they perceive a positive image of the event or festival.

While some studies mentioned the importance of destination image especially in affecting visitor revisit intention, the relationship between these constructs is still equivocal. Chi and Qu (2008) found that the image of Eureka Springs in Arkansas does not influence the intention of visitors to revisit the destination. Furthermore, Hernández-Lobato, SolisRadilla, Moliner-Tena, and Sánchez-García (2006) explain that only affective image has a positive effect on behavioural intention. This study does not find the effect of cognitive image on loyalty. Apart of this inconsistent relationship, the nature relationship between these constructs is also not clear. Some studies (Chen \& Tsai, 2007; Hernández-Lobato et al., 2006) claim that the image of a tourism destination directly influence behavioural intention while other studies (Lee, 2009; Prayag \& Ryan, 2012) indicate that destination image indirectly affect behavioural intention.

Furthermore, scholars contend that an event should have an ability to make visitors aware about the presence of the event (C. Mason \& Stark, 2004; Yi, Jonathon, \& Liping, 2011). The concept of event awareness is derived from the concept of brand awareness. Keller (1993) suggests that brand awareness relates to the possibility of brand name come to customer mind. Thus, brand awareness would be able to influence the visitors to revisit a particular event or festival. 
Some studies have declare the importance of brand awareness especially in creating customer loyalty (Clottey, Collier, \& Stodnick, 2008; Hutter, Hautz, Dennhardt, \& Füller, 2013; Malik \& Ghafoor, 2013). In the area of destination branding, scholars (Macdonald \& Sharp, 2000; M. Mason \& Nassivera, 2013; Oh, 2000) also found the role of awareness in shaping behavioural intention. These studies explain that there is a positive effect of brand awareness on tourist behavioural intention. The higher the awareness of a particular event, the higher the intention of visitor to revisit the event.

While the importance of awareness in affecting behavioural intention have been recognized widely, there is still no consensus among scholars about the relationship between event or festival awareness and revisit intention. M. C. Mason and Nassivera, (2013) and Yuan and Jang (2008) proposed that event awareness has a direct effect on loyalty. However, Boo, Busser, and Baloglu (2009) and Oh (2000) claim that the effect of awareness should be mediated by a mediating variable before affecting loyalty.

Another gap identified in the literature is about the nature of event investigated. Most of studies investigating mega event (Esu \& Arrey, 2009; Gibson et al., 2008; Hsing-Hui Lin, 2011). To date, no published studies have been found in investigating a local regular event especially in the setting of Indonesia. For that reason, this study would take ljen Car Free Day (ICFD) as the setting of the study. ICFD is a weekly moment held in Malang, East-Java Province Indonesia. The main objective of ICFD is to provide an open space for Malang people to have an activity and interaction with other people. In addition, ICFD also provides benefit for Malang city as a tourism destination.

Based on the gaps in literatures and the background, this study aims:

1. To investigate the effect of event awareness and event image on people revisit intention

2. To investigate the effect of event awareness on event image

3. To determine the mediating effect of event image in the relationship between event awareness and revisit intention.

Upon the completion of these three research objectives, this study contributes to both theoretical and practical perspectives. For theoretical perspective, this study will theoretically provide evidence about the relationships among event awareness, event image and revisit intention. In addition, this study would determine the mediating role of event image in the relationship between event awareness and revisit intention. For practical perspective, this study would be a guideline for tourism practitioners in creating a strategy to make people revisit an event especially a regular event.

\section{Literature Review}

\subsection{Event Revisit Intention}

Revisit intention is regarded as an important topic in tourism destinations area. Although some studies have been addressed to investigate repeat visitors behaviour, the reasons why people perform a revisit behaviour and what kind of destination characteristic hold repeat visitors are remain unclear (Mat Som, Marzuki, Yousefi, \& AbuKhalifeh, 2012). Scholars (Mat Som et al., 2012; Shoemaker \& Lewis, 1999) argue that retaining loyal customers is more cost-effective than attracting new customers. Chen and Tsai (2007) explain that understanding the relationships between future behavioural intention and its predictors, will help destination tourism managers to shape up an attractive image and improve their marketing strategy to maximize their use of resources. Tourist's behaviours may include the choice of destination to visit, the subsequent evaluations, and the future behavioral intentions. The travel experience or perceived value and the overall visitor's satisfaction can be considered as the subsequent evaluations, whereas the future behavioral intentions refer to the visitor's judgment about the likeliness to revisit the same destination and the willingness to recommend it to others.

Some researches noted the benefits of repeat purchase such as more cost-effective than getting new customers (Reichheld \& Sasser, 1990; Shoemaker \& Lewis, 1999). Furthermore, scholars (Reichheld \& Sasser, 1990; Shoemaker \& Lewis, 1999) claimed that increasing $5 \%$ in loyal customer could increase profit by up to $85 \%$. In addition, loyal customers tends to provide positive word-of-mouth endorsement. Hence, it is obvious that many travel spots depend heavily on repeat visitors (Darnell \& Johnson, 2001; Gitelson \& Crompton, 1984).

In their study, Mat Som et al.(2012) found that destination image, modern environment, and weather and natural attractions are the main factors of visitors to revisit Sabah. In Mat Som et al.'s (2012) study, destination image was found to be the most important factor affecting tourists' revisit intention. The friendliness of native people, the ability to communicate with local community, the local foods and the good value for money (destination image) are the main destination attributes that manifest Sabah's image as a tourist destination (Mat Som et al., 2012). 


\subsection{Event Awareness}

Theoretically, Keller (1993) suggests that brand awareness has two major dimensions. They are brand recall and brand recognition. While brand recall is the capability of individual to correctly generate the brand from the memory (Keller, 1993), brand recognition is about the ability of consumers to differentiate the brand as they previously have seen or heard. Rossiter and Percy (1987) contend that brand awareness is about the consumer's ability to recognise the brand under different conditions. Specifically, brand name awareness relates to the likelihood that a brand name will come to the mind of customers (Keller, 1993). Kotler and Keller (2012) identified that brand awareness consists of three dimensions; brand dominance, brand knowledge, and brand opinion.

Aaker (1996) declares that new or niche brands, brand recognition is important. However, for established brands, brand recall and are more essential and meaningful than brand recognition. Aaker (1996) and, Chieng and Lee (2011) explain that brand knowledge and brand opinion are essential to the measurement of brand recall. Rajh (2002) contends the importance of brand awareness in affecting consumer decision making. First, a consumer who are aware with a brand is more likely to include the brand in his/her consideration set (Keller, 1993; Rajh, 2002). Second, brand awareness can affect consumer's decisions making, especially in the low-involvement consumers. In low-involvement consumers, brand awareness is essential as minimum level of awareness can still affect consumers' decision on choosing a brand. The effect of low-level brand awareness on the low-invovement consumers' decision making is the result from either a lack of consumer motivation (i.e., consumers do not care about the product or service) or a lack of consumer ability (i.e., consumers do not know anything else about the brands) (Keller, 1993; Rajh, 2002).

In the area of destination branding, some researchers (Hsing-Hui Lin, 2011; Myagmarsuren \& Chen, 2011) found that there is a significant relationship between event awareness and event image. Hsing-Hui Lin (2011) shows that individual's awareness toward Mazu religious event significantly influence the event image. Specifically, this study found that the higher event awareness, the more positive image of the event in the visitor's mind. Similar to Lin's study, Myagmarsuren and Chen (2011) found that tourists awareness about destination object in Mongolia significantly influence the perception about the image of the place.

In addition, some studies found that the events or festivals which have a higher brand awareness would be able to create loyalty among the visitors (Boo et al., 2009; Lai, Hsu, Lin, Chen, \& Lin, 2014; C. Mason \& Stark, 2004). Based on these prior studies, hypotheses proposed in this study are:

H1: Event awareness has a positive effect on visitor's revisit intention

H2: Event awareness has a positive effect on event image

\subsection{Event Image}

The concept of event image was derived from the concept of brand image. Scholars suggest that brand image is an importance notion in marketing study (Gardner \& Levy, 1955; Keller, 1993). Kotler and Keller (2012) defined brand image as the perceptions and beliefs held by consumer, as reflected in the associations held in consumer memory. Apart of brand association, scholars Plummer (2000) suggests that brand personality is a robust element of positive brand image.

An event as an element of tourism destination needs to have a positive image. Destination image refers to an individual's mental illustration of knowledge, feelings, and general perception of a particular destination (Assaker, Vinzi, \& O'Connor, 2011; Fakeye \& Crompton, 1991). Assaker et al.(2011) contend that the destination with a positive image is more likely to be included and selected on the process of decision making. Furthermore, destination image is considered as an important factor since travel destinations predominantly compete on perceived image (Baloglu \& Mangaloglu, 2001).

Prior studies found that event image plays an important role in branding strategy. Hsing-Hui Lin (2011) on his study indicates that event brand image positively influences event brand loyalty of Mazu religious events. This finding shows that the more positive image of the events the higher loyalty of individual toward the event. Similar to this study, the study of Hernández-Lobato et al.(2006) indicate that cognitive and affective image have a positive effect on individual's behavioural intention in visiting Ixtapa-Zihuatanejo Mexico. The importance of destination image in shaping individual's loyalty is also found by Cai, Wu, and Bai (2003). Particularly this study shows that both affective and attitude image have an effect on customer loyalty. Apart from these studies, other scholars such as Assaker et al.(2011), Chen and Tsai (2007) and Chi and Qu (2008) indicate that in the area of destination branding, image has an effect on behavioural intetion. However, the effect is considered as an indirect effect since it is mediated by mediating variables.

By having some evidences about the relationship between image and behavioural intention. This study predicts that there is a relationship between the image of a regular event and people revisit intention. Hence, this study proposes: 
H3: There is a positive effect of regular event image on revisit intention

$\mathrm{H} 4$ : Event image mediates the effect of event awareness on revisit intention

Based on the review of literature, a conceptual model is proposed by this study. Figure 1 depicts the conceptual model used in this study.

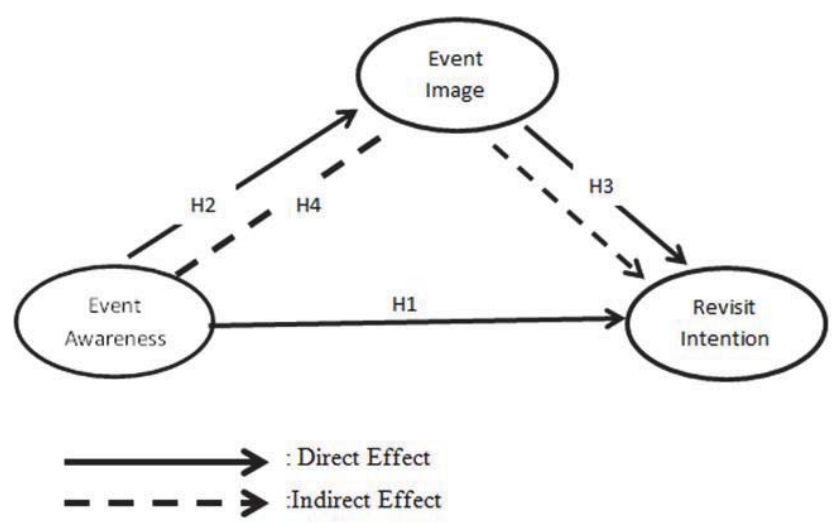

Figure 1. Research Model

\section{Research Method}

\subsection{Sample}

The sample population of this study is individuals who visited ICFD. Since, it is difficult in determining the total population of people visited ICFD and the inequality in being chosen as participants, this study employed convenience sampling procedure in collecting the data. Because of the core objective from this study is to test the interrelationships among constructs (i.e event awareness, event image and revisit intention), non-probability sampling approach is considered acceptable.

Self-administered questionnaires were circulated to 250 ICFD visitors using a personal approach where the visitors were personally asked to answer the questionnaire. A total of 250 questionnaires were distributed whereas 205 that might be used for this study yielded $82 \%$ response rate.

\subsection{Measurement}

In this study, the questionnaire survey was done to collect empirical data. The questionnaire was designed based on a review of the related literature. The questionnaire consisted of two parts. The first part collects information about the demographic of respondents; and, the second part measures the variables investigated in this study. The measures used in this study were adapted from several studies measuring event awareness, event image and revisit intention.

The questionnaire examining event awareness is adapted from Boo et al.,(2009) and Chieng and Lee (2011). In this study event awareness is measured by seven items. In measuring event image, seven items are used by this study. The measures of event image are adapted from Boo et al. (2009) and Woisetschläger (2007). The question to measure revisit intention Boo et al. (2009), Luo and Hsieh (2013) and Pike, Bianchi, Kerr, and Patti (2010). Apart from the questions about respondent's demographics, which were measured by categorical scales, a five-point Likert scale ranging from 'strongly disagree (1)' to 'strongly agree (5)' are used to all the other constructs.

\subsection{Data Analysis}

To analyse the data and testing the hypotheses, this study employs Structural Equation Modelling (SEM) with maximum likelihood method. In analysing the data, a confirmatory factor analysis was first conducted to examine whether the 
manifest measurement items used in this study reflected the latent constructs. To test the goodness of fit of the model, this study used three fit indices. They are absolute fit indexes (Goodness of Fit/GFI), incremental fit indexes (Normed Fit Indexes/NFI and Comparative Fit Index/CFI) and parsimonious fit indexes (Normed Square/ $x^{2} / d f$ and Parsimony Goodness-of-fit Index/PGFI). The cut-off value for GFI,NFI and CFI is above 0.9, $X^{2} /$ df less than 5.0, and PGFI more than 0.5. These cut-off value indicate that the model is fit (Kline, 2005).

\section{Results}

\subsection{Description of Respondents}

The followings are demographic profile emerged from the sample: $67 \%$ of the respondents are female, around $59 \%$ are aged between 20 and 29 years, $84 \%$ have minimum high school education, and $86 \%$ have job as a student. Table 1 presents the demographic of respondents of this study.

Table 1. Demographic Data

\begin{tabular}{|c|c|c|}
\hline Gender & Female & $67 \%$ \\
\hline & Male & $33 \%$ \\
\hline Education & High School & $84 \%$ \\
\hline & Diploma Degree & $1 \%$ \\
\hline & Bachelor Degree & $15 \%$ \\
\hline Age & $<20$ & $40 \%$ \\
\hline & $20-29$ & $59 \%$ \\
\hline & $40-49$ & $1 \%$ \\
\hline Job & $50-59$ & $0 \%$ \\
\hline & Students & $86 \%$ \\
\hline & Employees & $9 \%$ \\
\hline & Entrepreneur & $5 \%$ \\
\hline
\end{tabular}

\subsection{Measurements}

Prior testing the structural model, measurement model was assessed using Confirmatory Factor Analysis (CFA). In this CFA, all constructs involved were assumed to covary each other as suggested by Kline (2005). The results of CFA from the measurements model indicate the goodness of fit indexes specified a poor model $(\mathrm{GFI}=0,814 ; \mathrm{NFI}=0,754 ; \mathrm{CFI}=$ 0,$834 ; x^{2} / d f=2,509$ and PGFI $\left.=0,656\right)$. Since, the indexes of goodness of fit are considered in the poor level of fit, there is a need to improve the model fitness. The model modification was conducted by excluding item EA4, EA,5, EA6, EA7, EI1, E2, EI4, ERI6 and ERI7 from the model and draw covariance between er12 and er13 where it resulted a fit model $\left(\mathrm{GFI}=0,934 ; \mathrm{NFI}=0,921 ; \mathrm{CFI}=0,961 ; x^{2} / d f=1,883\right.$ and $\left.\mathrm{PGFI}=0,598\right)$.

Apart of examining the goodness of fit model, composite reliability and factor loadings were also examined by this study. The evaluation shows that the composite reliability of all constructs were above the cut-off level of 0,60 and all constructs also satisfied the minimum variance extracted value of 0,50 (Bagozzi \& Yi, 1988). These results mean the variance due to measurement error was less than the variance captured by the construct. Thus, the constructs were considered as reliable and satisfied the internal consistency requirement.

To confirm that there is no convergent validity problem, the score of factor loading is assessed. Hair, Black, Babin, Anderson and Tatham (2010) suggest that to be free with convergent validity problem, the constructs are used should have factor loading above 0,6 . The results of convergent validity test indicate that all constructs have factor loading above the cut-off value. Table 2 summaries factor loadings and composite reliability 
Table 2: Factor loadings, average variance extracted and composite reliability

\begin{tabular}{|c|c|c|c|}
\hline Item & Questions & Factor Loading & Composite Reliability \\
\hline & ljen Car Free Day (ICFD) has a good reputation & 0,617 & \multirow{3}{*}{0,688} \\
\hline EA2 & ICFD is familiar to me & 0,633 & \\
\hline EA3 & ICFD is well known & 0,702 & \\
\hline El3 & I would be proud to visit ICFD & 0,609 & \multirow{4}{*}{0,866} \\
\hline & ICFD is likeable & 0,761 & \\
\hline El6 & ICFD is unique & 0,840 & \\
\hline El7 & ICFD is attractive & 0,916 & \\
\hline ERI1 & I intend to visit this event within the next month & 0,679 & \multirow{5}{*}{0,848} \\
\hline ERI2 & I revisit ICFD because of free attraction, i.e. Aerobic, music performance & 0,682 & \\
\hline ERI3 & I revisit ICFD because it is interesting for me & 0,884 & \\
\hline ERI4 & I revisit ICFD because I am satisfied & 0,771 & \\
\hline ERI5 & ICFD is worth to be visited again & 0,604 & \\
\hline
\end{tabular}

Discriminant validity which refers to the degree to which conceptually similar concepts are distinct (Hair, Black, \& Babin, 2010) was assessed by testing the correlation coefficients between different constructs (Kline, 2005). The results of discriminant validity test indicated that the correlations among constructs are below 0,85 which means there is no discriminant validity problem (Kline, 2005). In addition, by having the score or correlation below 0,90 for each construct, it also can be said that the model proposed is free from multicollinearity problem (Hair, Black, \& Babin, 2010). Table 3 shows that correlations among constructs.

Table 3. Correlations Among Constructs

\begin{tabular}{|l|c|c|c|}
\hline & Event Awareness & Event Image & Event Revisit Intention \\
\hline Event Awareness & 1 & & \\
\hline Event Image & 0,48 & 1 & \\
\hline Event Revisit Intention & 0,45 & 0,74 & 1 \\
\hline
\end{tabular}

\subsection{Structural Model}

Structural equation model was designed to examine the possible relationships that might exist among event awareness, event image and visitor revisit intention. This structural model consist one exogenous variable (event awareness) and two endogenous variables (event image and revisit intention). Prior testing the proposed hypotheses, the goodness of fit model was tested which the results indicated a good model fit to the sample data $(\mathrm{GFI}=0,908 ; \mathrm{NFI}=0,892 ; \mathrm{CFI}=0,947$; $x^{2} / d f=1,810$ and PGFI = 0,592). By having a good model fit, model modification was not necessary to be conducted.

In testing direct relationships, this study set up alpha $5 \%$ with t-statistic is 1,960. Hypothesis 1 proposed that event awareness is a robust determinant of visitor's revisit intention. The statistical estimation shows that there is no direct significant effect of event awareness on visitor revisit intention ( $t=1,428 ; \beta=0,058)$. This insignificant effect means Hypothesis 1 is not supported. While there is no a significant effect of event awareness on visitor revisit intention, this study found that there is a positive significant relationship between event awareness and event image $(t=4,881 ; \beta=$ $0,554)$. It indicates that the higher visitor awareness about the event, the more positive image perceived by the visitors (Hypothesis 2 is supported). The effect of event image on revisit intention is proposed by Hypothesis 3 . The hypothesis testing explain that there is a positive significant effect of event image on visitor revisit intention $(t=6,367 ; \beta=0,283)$. This finding means the more positive the image of the event, the higher visitor's intention to revisit the event.

The indirect effect of event awareness on visitor revisit intention through event image is proposed by Hypothesis 4. To test this hypothesis, mediation analysis steps proposed by Baron and Kenny (1986) are employed. Furthermore, Sobell's test is used to generate the value of t-statistics. Following Baron and Kenny's (1986) mediation test analysis, an indirect effect is found when predictor has an impact on mediator and mediator significantly influence criterion. In this study, event awareness is considered as predictor. The statistical estimation shows that event awareness has an impact on event image and event image is a robust predictor of revisit intention. The sobell's calculation indicates that t-statistic is 3,855. It means there is a significant indirect effect of event awareness on revisit intention (Hypothesis 4 is supported). Since, event awareness only having an indirect effect on visitor revisit intention, this mediating effect is considered as a 
fully mediation effect.

Table 4 summarizes the results of hypotheses testing.

Table 4. Hypothesis Testing

\begin{tabular}{|c|l|c|l|}
\hline Hypothesis & Path & t-statistic & Results \\
\hline $\mathrm{H} 1$ & $\mathrm{EA} \rightarrow \mathrm{ERI}$ & 1,428 & Not-supported \\
\hline $\mathrm{H} 2$ & $\mathrm{EA} \rightarrow \mathrm{EI}$ & $4,881^{\star \star \star}$ & Supported \\
\hline $\mathrm{H} 3$ & $\mathrm{EI} \rightarrow \mathrm{ERI}$ & $6,367^{\star \star *}$ & Supported \\
\hline $\mathrm{H} 4$ & $\mathrm{EA} \rightarrow \mathrm{EI} \rightarrow \mathrm{ERI}$ & $3,885^{\star \star \star}$ & Supported \\
\hline
\end{tabular}

*** significant at the level 0,001

\section{Discussion and Conclusion}

The notion of image has been acknowledged widely as an important constructs in the area of marketing studies. Some studies have found that brand image (Kandampully \& Suhartanto, 2000; Suhartanto et al., 2013) and corporate image (Clemes, Shu, \& Gan, 2014; Wallin Andreassen \& Lindestad, 1998) play an important role in creating customer loyalty. Similar to that notion, this study found that event image is an important construct to affect visitors to revisit a particular regular event. The finding indicates that the more positive the image of the event, the higher the intention of visitor to revisit.

Both uniqueness and attractiveness of the event are the important dimensions of an event image. As a regular event is an event which is held regularly, there is a need of visitors to have a reason to revisit the event. A unique and attractive event would bring values for visitors to revisit an event. The more unique and attractive an event would lead into a more positive image. This finding explains that all parties involved in the event must be creative. They should be able to create an event which is different with other events. Since a regular event is held regularly, the event organizer supposed to make a particular theme for each single event. Otherwise, visitors would be bored and they would perceive that the event has a bad image which finally make them not to come to the event in future.

Apart of its essential role in affecting visitor's revisit intention, the image of an event is also important as a mediator in the relationship between event awareness and revisit intention. Previous studies mentioned that event awarenes has a direct effect on revisit intention. However, this direct effect was not found in this study. Although this study did not find the direct effect of event awareness on revisit intention, this study provides evidence that awareness affects revisit intention through the perception about image. It can be interpreted that, the higher visitor's awareness about the regular event would lead into the more positive image perceived by visitors which finally bring into loyalty.

The findings of this study provide contributions for both theoretical and practical perspective. Theoretically, the model built up in this study provides an insight about the importance of event image in the context of destination branding. This study shows that event image is a robust predictor of visitor's revisit intention. In addition, the finding of this study contends that event image plays a mediating effect in the relationship between event awareness and revisit intention. Apart of its theoretical contributions, this study specifies practical contributions. For event management practitioners, this study shows a comprehensive and systematic picture about the way which can be taken by regular event managers to enhance the number of visitors. In addition, this study explains strategies to improve the image of an event which is important to increase the loyalty of visitors.

While this study makes a contribution to the body of tourism marketing literature, some limitations were identified in this study. First limitation relates to sample design. Although this study has a relatively large sample $(n=205)$, respondents were the visitor of ljen Car Free Day Malang. Given that a convenience sampling approach was collect the data, the sample does not represent the population of Indonesian regular event visitors. Another limitation is about the use of self-administered questionnaire to collect the data. On the self-administered method researcher has a small control which might lead to misinterpretation by participants. This misinterpretation could create validity problems. To minimize this misinterpretation, questions were designed simple, concise and specific. In addition, the questionnaire avoid double negative questions and double-barrelled questions (combining two or more issues in a single question).

In order to get a deeper understanding of regular event re-visit intention, future research could add other construct such as event quality, visitor experience and visitor satisfaction in the model. In addition, exploring the moderating role of demographic variables, for example age and gender will enhance the comprehensiveness of the study.

This study is based on the Indonesian setting, and the results cannot be generalized. Thus, the research on the importance of event awareness and event image on event re-visit intention in other settings will be beneficial. 


\section{References}

Aaker, D. A. (1996). Measuring brand equity across products and markets. California Management Review, 38(3), 103.

Assaker, G., Vinzi, V. E., \& O'Connor, P. (2011). Examining the effect of novelty seeking, satisfaction, and destination image on tourists' return pattern: A two factor, non-linear latent growth model. Tourism Management, 32(4), 890-901. doi:10.016/j.tourman. 2010.08.004

Bagozzi, R. P., \& Yi, Y. (1988). On the Evaluation of Structural Equation Models. Journal of the Academy of Marketing Science, 16(1), 74-94. doi:10.1177/009207038801600107

Baloglu, S., \& Mangaloglu, M. (2001). Tourism destination images of Turkey, Egypt, Greece, and Italy as perceived by US-based tour operators and travel agents. Tourism Management, 22(1), 1-9. doi:10.1016/S0261-5177(00)00030-3

Baron, R. M., \& Kenny, D. A. (1986). The moderator-mediator variable distinction in social psychological research: Conceptual, strategic, and statistical considerations. Journal of Personality and Social Psychology, 51(6), 1173.

Bloemer, J., \& de Ruyter, K. (1998). On the relationship between store image, store satisfaction and store loyalty. European Journal of Marketing, 32(5/6), 499-513. doi:10.1108/03090569810216118

Boo, S., Busser, J., \& Baloglu, S. (2009). A model of customer-based brand equity and its application to multiple destinations. Tourism Management, 30(2), 219-231. doi:10.1016/j.tourman.2008.06.003

Cai, L. ., Wu, B. (Tiger), \& Bai, B. (2003). Destination Image and Loyalty. Tourism Review International, 7(3), 153-162. doi:10.3727I 1544272031437656

Cai, L. A. (2002). Cooperative branding for rural destinations. Annals of Tourism Research, 29(3), 720-742. doi:10.1016/S01607383(01)00080-9

Chen, C. F., \& Tsai, D. (2007). How destination image and evaluative factors affect behavioral intentions? Tourism Management, 28(4), 1115-1122. doi:10.1016/j.tourman.2006.07.007

Chi, C. G.-Q., \& Qu, H. (2008). Examining the structural relationships of destination image, tourist satisfaction and destination loyalty: An integrated approach. Tourism Management, 29(4), 624-636. doi:10.1016/j.tourman.2007.06.007

Chieng, F. Y. L., \& Lee, G. C. (2011). Customer-Based Brand Equity : a Literature Review. Journal of Arts Science \& Commerce, II(1), 33-42.

Clemes, M. D., Shu, X., \& Gan, C. (2014). Mobile communications: a comprehensive hierarchical modelling approach. Asia Pacific Journal of Marketing and Logistics, 26(1), 114-146.

Clottey, T. a, Collier, D. a, \& Stodnick, M. (2008). Drivers Of Customer Loyalty In A Retail Store Environment. Journal of Service Science, 1(1), 35-48.

Darnell, A. C., \& Johnson, P. S. (2001). Repeat visits to attractions: a preliminary economic analysis. Tourism Management, 22(2), 119126. doi:10.1016/S0261-5177(00)00036-4

Esu, B., \& Arrey, V. (2009). Branding Cultural Festival as a Destination Attraction: A Case Study of Calabar Carnival Festival. International Business Research, 2(3). Retrieved from http://www.ccsenet.org/journal/index.php/ibr/article/view/2895

Fakeye, P. C., \& Crompton, J. L. (1991). Image Differences between Prospective, First-Time, and Repeat Visitors to the Lower Rio Grande Valley. Journal of Travel Research, 30(2), 10-16. doi:10.1177/004728759103000202

Gardner, B. B., \& Levy, S. J. (1955). The product and the brand. Harvard Business Review, 33(2), 33-39.

Gibson, H. J., Qi, C. X., \& Zhang, J. J. (2008). Destination image and intent to visit China and the 2008 Beijing Olympic Games. Journal of Sport Management, 22, 427-450.

Gitelson, R. J., \& Crompton, J. L. (1984). Insights into the repeat vacation phenomenon. Annals of Tourism Research, 11(2), 199-217. doi:10.1016/0160-7383(84)90070-7

Hair, J. F., Black, W. C., \& Babin, B. (2010). Multivariate Data Analysis: A Global Perspective. Pearson Education. Retrieved from http://books.google.com/books?id=SLRPLgAACAAJ\&pgis=1

Hair, J. F., Black, W. C., Babin, B. J., Anderso, R. E., \& Tatham, R. L. (2010). Multivariate data analysis (7th ed.). New Jersey: Prenticen Hall.

Hernández-Lobato, L., Solis-Radilla, M. M., Moliner-Tena, M. A., \& Sánchez-García, J. (2006). Tourism Destination Image, Satisfaction and Loyalty: A Study in Ixtapa-Zihuatanejo, Mexico. Tourism Geographies, 8(4), 343-358. doi:10.1080/14616680600922039

Hsing-Hui Lin, M. S. (2011). A multidimensional customer-based brand equity and its application to religious events: The case of Mazu. Texas Tech University.

Hutter, K., Hautz, J., Dennhardt, S., \& Füller, J. (2013). The impact of user interactions in social media on brand awareness and purchase intention: the case of MINI on Facebook. Journal of Product \& Brand Management, 22(5), 342-351. doi:10.1108/JPBM05-2013-0299

Kandampully, J., \& Suhartanto, D. (2000). Customer loyalty in the hotel industry: the role of customer satisfaction and image. International Journal of Contemporary Hospitality Management, 12(6), 346-351.

Kaplanidou, K., \& Vogt, C. (2007). The Interrelationship between Sport Event and Destination Image and Sport Tourists' Behaviours. Journal of Sport \& Tourism, 12(3-4), 183-206. doi:10.1080/14775080701736932

Keller, K. L. (1993). Conceptualizing, measuring, and managing customer-based brand equity. Journal of Marketing, 57(1), 1-22. doi:10.2307/1252054

Kline, R. B. (2005). Principles and Practice of Structural Equation Modeling. Guilford Press. Retrieved from http://books.google.co.id/ books?id=EkMVZUxZrglC 
Kose, H., Argan, M. T., \& Argan, M. (2011). Special event management and event marketing: A case study of TKBL all star 2011 in Turkey, 8, 1-11. Retrieved from http://search.ebscohost.com/login.aspx?direct=true\&db=bth\&AN=74534618\&site=eds-live\& scope=site\&authtype=shib\&custid=s5575886

Kotler, P., \& Keller, K. L. (2012). Marketing Management. Pearson Education. Retrieved from https://books.google.com/books?id=I8y NIAEACAAJ\&pgis=1

Lai, Y.-L., Hsu, M.-S., Lin, F.-J., Chen, Y.-M., \& Lin, Y.-H. (2014). The effects of industry cluster knowledge management on innovation performance. Journal of Business Research, 67(5), 734-739. doi:10.1016/j.jbusres.2013.11.036

Lee, T. H. (2009). A Structural Model to Examine How Destination Image, Attitude, and Motivation Affect the Future Behavior of Tourists. Leisure Sciences, 31(3), 215-236. doi:10.1080/01490400902837787

Luo, S. J., \& Hsieh, L. Y. (2013). Reconstructing revisit intention scale in tourism. Journal of Applied Sciences, 13(18).

Macdonald, E. K., \& Sharp, B. M. (2000). Brand Awareness Effects on Consumer Decision Making for a Common, Repeat Purchase Product: Journal of Business Research, 48(1), 5-15. doi:10.1016/S0148-2963(98)00070-8

Malik, M. E., \& Ghafoor, M. (2013). Importance of Brand Awareness and Brand Loyalty in assessing Purchase Intentions of Consumer. International Journal of Business and Social Science, 4(5), 167-171.

Mason, C., \& Stark, M. (2004). What do Investors Look for in a Business Plan?: A Comparison of the Investment Criteria of Bankers, Venture Capitalists and Business Angels. International Small Business Journal, 22(3), 227-248. doi:10.1177/0266242604042377

Mason, M., \& Nassivera, F. (2013). A Conceptualization of the Relationships Between Quality, Satisfaction, Behavioral Intention, and Awareness of a Festival. Journal of Hospitality Marketing \& Management, 22(2), 162-182. doi:10.1080/19368623.2011.643449

Mat Som, A. P., Marzuki, A., Yousefi, M., \& AbuKhalifeh, A. N. (2012). Factors Influencing Visitors' Revisit Behavioral Intentions: A Case Study of Sabah, Malaysia. International Journal of Marketing Studies, 4(4). doi:10.5539/ijms.v4n4p39

Moon, K.-S., Ko, Y. J., Connaughton, D. P., \& Lee, J.-H. (2013). A mediating role of destination image in the relationship between event quality, perceived value, and behavioral intention. Journal of Sport \& Tourism, 18(1), 49-66. doi:10.1080/14775085.2013.799960

Myagmarsuren, O., \& Chen, C.-F. (2011). Exploring relationships between destination brand equity, satisfaction, and destination loyalty: A case study of Mongolia. Journal of Tourism, Hospitality \& Culinary Arts, 3(2), 81.

Oh, H. (2000). The Effect of Brand Class, Brand Awareness, and Price on Customer Value and Behavioral Intentions. Journal of Hospitality \& Tourism Research, 24(2), 136-162. doi:10.1177/109634800002400202

Pike, S., Bianchi, C., Kerr, G., \& Patti, C. (2010). Consumer-based brand equity for Australia as a long haul tourism destination in an emerging market. International Marketing Review, 27(4).

Plummer, J. T. (2000). How Personality Makes a Difference. Journal of Advertising Research, 40(06), 79-84. Retrieved from http://journals.cambridge.org/abstract S002184990000012X

Prayag, G., \& Ryan, C. (2012). Antecedents of Tourists' Loyalty to Mauritius: The Role and Influence of Destination Image, Place Attachment, Personal Involvement, and Satisfaction. Journal of Travel Research, 51(3), 342-356. doi:10.1177/0047287511410321

Rajh, E. (2002). Development of a scale for measuring customer-based brand equity. Ekonomski Pregled, 7(7-8), 770-781. doi:10.1016/j.annals.2006.10.005

Reichheld, F. F., \& Sasser, W. E. (1990). Zero defections: quality comes to services. Harvard Business Review, 68(5), 105-11. Retrieved from http://europepmc.org/abstract/med/10107082

Rossiter, J. R., \& Percy, L. (1987). Advertising and promotion management. McGraw-Hill series in marketing.

Shoemaker, S., \& Lewis, R. C. (1999). Customer loyalty: the future of hospitality marketing. International Journal of Hospitality Management, 18(4), 345-370. doi:10.1016/S0278-4319(99)00042-0

Suhartanto, D., Clemes, M., \& Dean, D. (2013). Analyzing the Complex and Dynamic Nature of Brand Loyalty in the Hotel Industry. Tourism Review International, 17(1), 47-61. doi:10.3727/154427213X13649094288106

Trošt, K., Klarić, S., \& Ružić, M. D. (2012). Events as a Framework for Tourist Destination Branding - Case Studies of Two Cultural Events in Croatia, 16(2), 65-77.

Wallin Andreassen, T., \& Lindestad, B. (1998). Customer loyalty and complex services. International Journal of Service Industry Management, 9(1), 7-23. doi:10.1108/09564239810199923

Woisetschläger, D. M. (2007). Team-sponsorship in the formula one-does it affect brand perception? An empirical assessment in the German car market. Advances in Consumer Research, 34, 616-623.

Wong, J., Wu, H.-C., \& Cheng, C.-C. (2014). An Empirical Analysis of Synthesizing the Effects of Festival Quality, Emotion, Festival Image and Festival Satisfaction on Festival Loyalty: A Case Study of Macau Food Festival. International Journal of Tourism Research, n/a-n/a. doi:10.1002/jtr.2011

Yi, S., Jonathon, G., \& Liping, a. (2011). Moderate Effects of Brand Awareness on eWOM Intention: Perspectives in Community-based Festival Tourism. Retrieved from http://scholarworks.umass.edu/gradconf_hospitality/2011/Poster/14/

Yuan, J., \& Jang, S. (2008). The Effects of Quality and Satisfaction on Awareness and Behavioral Intentions: Exploring the Role of a Wine Festival. Journal of Travel Research, 46(3), 279-288. doi:10.1177/0047287507308322 